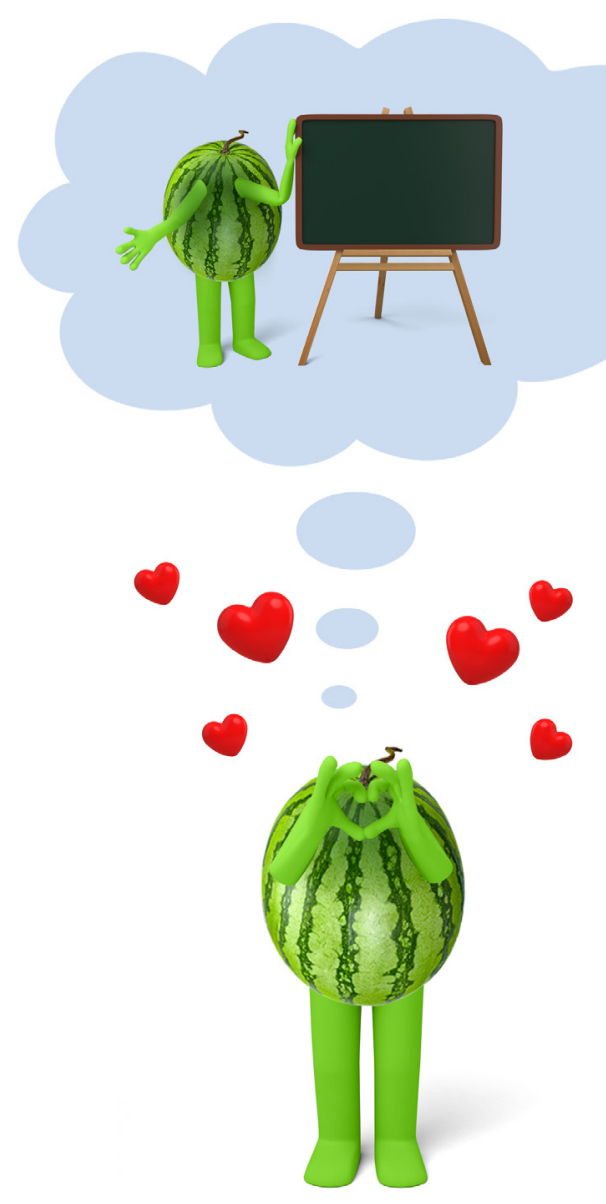

\title{
REASONS OF POLISH YOUNG POTENTIAL EMPLOYEES' INTEREST IN A UNIVERSITY AS THE EMPLOYER VR PERCEIVING ITS EMPLOYEES
}




\title{
Sciendo
}

\section{REASONS OF POLISH YOUNG POTENTIAL EMPLOYEES' INTEREST IN A UNIVERSITY AS THE EMPLOYER VR PERCEIVING ITS EMPLOYEES}

\author{
Professor Agnieszka Izabela Baruk \\ Łódź University of Technology, \\ Faculty of Management and Production Engineering, Poland \\ agnieszka.baruk@poczta.onet.pl •ORCID 0000-0003-2864-509X \\ DOI: 10.2478/minib-2019-0042
}

\section{Summary}

The article has a theoretical-empirical character. Its main goal was to identify reasons of young potential employees' interest in working at a university. To prepare the theoretical part, the method of cognitive-critical analysis of world literature on marketing, management and HRM was applied. The results of this analysis show an existing cognitive gap and a research gap in the scope of considerations about reasons of interest of the mentioned group of employees in a university as the employer. Striving for reducing both gaps some empirical researches were conducted using the questionnaire method to gather the primary data which were analyzed statistically using the method of exploratory factor analysis, Kruskal-Wallis test, etc. The obtained results made it possible to check three research hypotheses. The possibility to perform a satisfying job was not the key reason for the respondents' interest in working at a university. The internal structure of reasons for the respondents' interest in a university as the employer was different for the following two groups: 1/ people who think that university's employees are perceived in Poland better than those who work in other organizations; 2/ people who think that university's employees are perceived in Poland as well as those who work in other organizations. The way of perceiving employees of an university was a feature statistically significantly differentiating the reasons of the respondents' interest in starting work at the university only in the case of high social prestige and high wages.

Keywords: potential employee, university, employer, image

JEL : M31; M54 



\section{Introduction}

Each marketing offer is created for customers with specific expectations or even requirements, whose fulfilment is becoming more and more challenging due to the often very rapid changes (cf. E. Felix, 2015) that occur in them. Such an offer must attract the attention of buyers, arouse their interest, induce their willingness to acquire it and encourage them to purchase it. In order for a transaction to be concluded, all the elements listed above in the given sequence should occur (cf. A. Stankevich, 2017). The presented scheme applies both to products offered to final buyers on the consumer market, where it is most often analysed in the literature (e.g. by E. Hadiyati (2016), S. Hassan, S.Z.A. Nadzim, N. Shiratuddin (2015)), as well as to specific offers, such as personal products addressed to employees (current and potential).

Like any other marketing product, a personal product has specific characteristics given to it by the bidder, which in this case is the employer. These characteristics must meet the criterion of compliance with the expectations of the recipients in order to at least attract their attention and interest. More and more often, however, in order for interest to turn into a desire to own a given product, and consequently to purchase it, the features assigned to it must exceed the expectations of customers, positively surprising them. The high probability of effective competition for buyers can therefore be seen by equipping the product with features that not only meet their expectations, but also offer them added value in the form of attributes that they did not expect to find in the product. Of course, this must not be at the expense of not caring for the basic characteristics of the product in question, the perceived quality of which (cf. B. Schnurr, A. BrunnerSperdin, N.E. Stokburger-Sauer, 2017) is also very important to buyers.

In addition to the characteristics of the product itself, the second key driver for attracting and attracting attention to the product is the opinions on the product and its bidder from sources external to the buyer (cf. A. Stankevich, 2017) and its own experience with the product and/or bidder (cf. H. Willman-Iivarinen, 2017). Of particular importance in the 
case of external sources are persons who are the authority of the buyer (cf. S. Chakravarthy, G.V.B. Prasad, 2011) and sources reflecting the opinion of a large group of persons (cf. M. Livette, 2007) (e.g. Poles). Both opinions from such external sources and the personal experience of the buyer contribute to the shaping of a specific image of a given product, stimulating the buyer or discouraging him from using the offer. Therefore, it is extremely important to achieve a convergence between the buyer's opinions on the product and its provider and those of external sources, including Internet sources, as they play an increasingly important role in stimulating shopping (cf. N. Huete-Alcocer, 2017) and off-purchase behaviours.

Of course, the bidder has a much greater influence on the characteristics of the product and a lesser influence on their subjective evaluations. However, it may take action to increase the likelihood that the product will be given characteristics that are in line with the expectations of the purchasers and thus positively assessed by them. It is primarily about involving customers in the process of preparing an offer, treating them as its co-creators (cf. G. Bhalla, 2016), which allows for the humanisation of this process (cf. D.L. Robers, W. Darler, 2017). Such an approach is certainly advisable for all types of products, including personal products. Giving them features that attract the attention of buyers and arouse their interest is especially important in the case of universities and other scientific institutions, in line with the paradigm of joint value creation (cf. V. Ramaswamy, K. Ozcan, 2014; F. Writer, 2014) and being an example of open social innovation (cf. A. Olejniczak, 2019).

Universities function in an extremely competitive environment, competing for employees among themselves and with other organisations. Moreover, their functioning in Poland in the 21st century is marked by very frequent, radical and controversial changes, which have a negative impact on current employees, leading to the generation of often unfavourable opinions about the university as an employer. These opinions are strengthened by opinions coming from other sources, including non-personal ones (traditional and modern media, especially social media). Moreover, taking into account the fact that the aforementioned changes concern, among 
other things, increasingly higher requirements (scientific, research, etc.) imposed on employees, it becomes crucial to take effective measures aimed at both retaining valuable current employees and attracting valuable candidates, especially from the group of young potential employees. Particularly valuable in the context of meeting these challenges are people with an above-average level of emotional intelligence (cf. V. Mattingly, K. Kraiger, 2019) (including social, psychological and praxeological competences), which has been recognized as a key factor in achieving success by modern man, also in the role of an employee.

Despite the growing importance of these issues, universities as employers are still not analysed in the literature. Thus, theoretical considerations and empirical studies concerning the reasons for lack of interest in or willingness to undertake work at a university are not conducted. Therefore, we can talk about the existence of a cognitive and research gap in this respect. Research attention is focused on other groups of employers, mainly on manufacturing and service enterprises, where personal actions and their effectiveness in general are considered (e.g. T.-C. Huang, 2000; S. Abduli, 2013; B. Mazur, 2014; Ch. Voegtlin, M. Greenwood, 2016; H.G. Madanat, A.S. Khasawneh, 2018; E. Bombiak, A. Marciniuk-Kluska, 2019), or is more specific HR policy issues being examined, including recruitment activities (e.g. A. Visa, J. Khasawneh, 2019) Einolander, H. Vanharanta, 2015; Y. Acikgoz, 2019), the use of modern technologies (e.g. D.L. Stone, D.L. Deadrick, K.M. Lukaszewski, R. Johnson, 2015), motivating employees (e.g. through play (cf. J.W. Michel, M.J. Tews, D.G. Allen, 2019; B. Müceldili, O. Erdil, 2016)), etc. (e.g. through the use of new technologies (e.g. D.L. Stone, D.L. Deadrick, K.M. Lukaszewski, R. Johnson, 2015), motivating employees (e.g. through play (cf. J.W. Michel, M.J. Tews, D.G. Allen, 2019; B. Müceldili, O. Erdil, 2016)). It is worth noting that these considerations relate mainly to personnel activities aimed at current employees, while still much less attention is paid to aspects related to external HR activities or external personnel marketing. For universities, on the other hand, the level of preparation of graduates is mainly analysed against the background of the requirements of enterprises as employers (e.g. N. 
Chhinzer, A.M. Russo, 2018; T. Tóth-Téglás, E. Hlédik, L. Fónadová, 2016) or the ways of acquiring candidates for students (e.g. A. Özdemira, E. Tozlub, E. Æenc, H. Ateæoglu, 2016), still perceiving universities as mainly educational and research entities. However, there is no evidence that universities play an equally important role as employers.

Therefore, this article aims to achieve the main objective, which was to identify the reasons for the interest of young potential employees in working in a university. During its implementation, an attempt was also made to achieve the following specific objectives:

C1: determining the hierarchy of reasons for the interest of young potential employees in work at the university;

C2: defining opinions on the perception of university employees in Poland in comparison with the perception of persons employed in other organisations;

C3: identifying the internal structure of reasons for the interest of young potential employees in work at universities, who believe that university employees in Poland are better perceived than those employed in other organisations;

C4: identifying the internal structure of reasons for the interest of young potential employees in work at universities, who believe that university employees in Poland are perceived in the same way as persons employed in other organisations;

C5: comparison of internal structure of reasons of interest in work in a university identified for both groups of respondents;

C6: determining the diversity of indications concerning the reasons for the interest in working at a university due to the perception of university staff in comparison with the perception of people employed in other organisations;

C7: indications of general recommendations for universities to facilitate effective personnel actions aimed at young potential employees.

The following research hypotheses have been tested in the process of realization of the above mentioned goals: 
H1: the possibility of performing a satisfactory job is a key reason for the interest of young people in taking up employment at a university;

H2: the internal structure of reasons for the interest of young people in taking up employment at universities, who believe that university employees are perceived in Poland better than those working in other organisations, is different than the internal structure of reasons for the interest of young people in taking up employment at universities, who believe that university employees are perceived in the same way in Poland;

H3: opinions on the perception of university staff as compared to the perception of persons employed in other organisations are a feature differentiating the reasons for young people's interest in taking up employment in universities.

\section{General characteristics of empirical studies}

In order to achieve the objectives of this article and to verify the formulated research hypotheses, empirical research ${ }^{1}$, was conducted using the survey method to collect primary data. So far, 3 editions of these surveys have been carried out. During the first edition of the research, 150 students completing their studies at the 1st or 2nd degree of full-time studies as potential employees were covered, while in the 2nd and 3rd edition of the research sample size was 250 people each, representing the aforementioned segment of the labour market ${ }^{2}$. The research was of a direct nature, requiring personal contact between the researcher and the subjects studied. The first edition of the survey was carried out in the first half of 2016, the second edition in the first quarter of 2018 and the third one in the first quarter of 2019. All questionnaires of the questionnaire were qualified for quantitative analysis, which was possible thanks to the use of face-to-face contact with respondents. The collected primary data were subjected to quantitative analysis, using the method of analysis of average scores, the method of comparative analysis, the method of exploratory factor analysis and the Kruskal-Wallis independence test. 
During each edition of the survey respondents were presented with a set of the same 13 statements reflecting the reasons for their interest in university as a workplace. They were distinguished on the basis of the results of cognitive-critical analysis of the literature on the subject and the results of unstructured interviews preceding the first edition of the research. Each of these statements was to be assessed by the respondents in a five-stage Likert scale, in which the assessment of 5 meant definitely yes, 4 - yes, 3 - neither yes nor no, 2 - rather no, while 1 - definitely not. The use of such a scale is a necessary condition for the use of the factorial analysis method. In order to expand and deepen the analysis, in the third edition of the survey respondents were asked about their opinions on the perception of persons working at universities in Poland in comparison with the perception of persons working in other institutions. Answers given to this question during the statistical analysis were used to check the diversity of indications concerning the reasons for the interest in the university as an employer.

Factor analysis allowed for an in-depth analysis of the collected primary data. It is used to reduce the number of variables constituting primary data obtained from surveys and to detect structures in the relationships between these variables, in other words, to classify them (H. Abdi, L.J. Williams, 2010; M. Sztemberg-Lewandowska, 2008). This analysis was therefore used to reduce the number of variables affecting the category in question, i.e. the reasons for the university's interest in being an employer and to detect internal interdependencies in the relationships between these variables.

The main components method was used to isolate the factors, but it was important to determine their number. In order to determine the number of common factors (the so-called main components), the Kaiser's criterion technique was applied, which consists in leaving only those factors that have their own values greater than 1 . Each such factor explains a certain level of general variability of the considered system, determined by the percentage of variance, which can be interpreted as a measure of the explanation of the phenomenon. The factors were rotated using the standardized varimax method. Within the framework of particular factors, variables with the highest factor loads in relation to a given factor were distinguished (the value $\geq 0.7$ was assumed). 
In factor analysis, hidden factors are identified, which include features responsible for perception through their prism of the problem described in the question. Factor analysis, however, does not allow to find an answer whether the differentiation in terms of separating particular groups (e.g. perception of people working at a university) is statistically significant enough to be able to say that the respondents' opinions determined by the analysed answer are significantly different. This question is answered by the Kruskal-Wallis test (KW), which is an unparametric equivalent of ANOVA.

In order to find an answer to the question whether the differentiation in terms of separating particular groups (e.g. separated by opinions on the perception of people working at a university) is statistically significant enough to be able to say that the respondents' opinions determined by the analysed answer are significantly different, the Kruskal-Wallis test (KW) was applied.

From the point of view of statistical criteria, in the case of the KW test, the data do not have to meet many requirements. The only requirements to be met are (http://www.statystyka.az.pl/test-anovakruskala-wallisa.php; http://www.statystycy.pl/t4997_1_test_rangowy_ kruskala-wallisa.php_1_test_rangowy_kruskala-wallisa.php):

- the dependent variable should be measured on at least an ordinal scale (it can also be measured on a quantitative scale),

- observations in the analysed groups should be independent of each other, which means that a person in one group should not be in another compared group at the same time (this requirement is met by dichotomous questions allowing to divide respondents into two separate groups and one single choice).

The Kruskal-Wallis test as a non-parametric equivalent of one-way variance analysis is therefore used when the data does not meet the requirements for similar parametric tests and can be ordered according to specific criteria. It consists in verifying whether the number of independent results from the group comes from the same population or from a population with the same median. Individual samples do not have to be of the same size. Input data is a n-elementary statistical sample 
divided into ' $k$ ' separate survey groups of $n 1$ to $n k$.

The interpretation of the test may consist only in comparing the 'p' value with the assumed materiality level (usually 0.05 ) or in analysing the values of test statistics in case it is necessary to assess the 'power/power' of differences between groups. The high values of the test statistics indicate that there are differences in individual groups (i.e. against the hypothesis of equality in individual groups), and the higher the values, the greater the difference.

Statistical analysis of the collected primary data was performed with the use of IBM SPSS Statistics Ver. 22.

\section{Results of the conducted tests}

According to the conducted research, in 2019 the majority of respondents $(76.6 \%)$ did not consider taking up employment at a university in the future. Therefore, the trend of much greater interest of young people in employers other than universities has been observed for several years. However, it is worth looking at this result from a different perspective, not only seeing it as underestimating universities as employers, but also seeing it as a fact that almost one in four respondents declared their open attitude towards taking up employment at universities. Therefore, it seems important to know the reasons for such an attitude.

Table 1 shows that as many as 7 out of 13 analysed reasons were not decisively denied, including in the case of 3 reasons even a less categorical negative answer. These included 2 reasons, which received an average score of more than 4.00. This refers to 'the possibility of sharing one's knowledge with others' and 'the possibility of making a career'. The first of them was the only one to obtain more than half of the decisive positive indications. In total, there were at least $25 \%$ of such indications in the case of 6 reasons, including all the analysed reasons why the average value was 4.00 or higher. The only reason that was definitely denied by more than one in ten respondents was 'more 
free time than in other places'. It is worth noting that apart from this reason, in the case of 2 other reasons the total share of negative indications exceeded $1 / 3$.

Table 1. Reasons for interest in working at a university indicated by the respondents

\begin{tabular}{l|r|r|r|r|r|r}
\hline \multicolumn{1}{c}{ Analysed reason } & \multicolumn{5}{c}{ Indications in \% } \\
\cline { 2 - 7 } & $\mathbf{1}$ & $\mathbf{2}$ & $\mathbf{3}$ & $\mathbf{4}$ & $\mathbf{5}$ & Average value \\
\hline Very easy and pleasant job & 9.7 & 25.8 & 38.7 & 22.6 & 3.2 & 2.84 \\
High social prestige & 0.0 & 6.4 & 9.7 & 58.1 & 25.8 & 4.03 \\
High salary & 0.0 & 9.8 & 29.0 & 45.2 & 16.0 & 3.67 \\
Possibility of making a career & 0.0 & 0.0 & 12.9 & 61.3 & 25.8 & 4.13 \\
Employment security and stability & 0.0 & 0.0 & 25.8 & 54.8 & 19.4 & 3.93 \\
Possibility of sharing one's knowledge with others & 0.0 & 0.0 & 3.2 & 45.2 & 51.6 & 4.48 \\
Possibility to impress others & 3.1 & 0.0 & 16.1 & 61.3 & 19.5 & 3.94 \\
Possibility to "be forever young" through & & & & & & \\
$\quad$ continuous contact with young people & 6.5 & 29.0 & 35.5 & 22.6 & 6.5 & 2.94 \\
More free time than in other places & 12.9 & 22.6 & 41.9 & 19.4 & 3.2 & 2.77 \\
Very responsible and difficult but & & & & & & \\
$\quad$ rewarding job & 0.0 & 9.7 & 32.3 & 38.7 & 19.3 & 3.68 \\
Positive overall impressions from studies & 0.0 & 3.2 & 22.6 & 45.2 & 29.0 & 4.00 \\
Positive experiences as a student related & & & & & & \\
$\quad$ to contacts with lecturers & 3.2 & 6.5 & 29.3 & 32.3 & 28.7 & 3.76 \\
Willingness to introduce better standards & & & & & & \\
in university work and eliminate mistakes & & & & & & \\
made by lecturers & 3.2 & 6.5 & 29.0 & 32.3 & 29.0 & 3.77 \\
\hline
\end{tabular}

where: 1 - definitely not; 2 - rather not; 3 - neither yes nor no; 4 - rather yes; 5 - definitely yes

Source: Own elaboration based on the results of conducted research.

Taking into account the ranges of average values used in previous editions of the survey (cf., among others, A. Baruk, A. Goliszek, 2018) for the analysis of associations with a university as an employer and reasons for not being interested in taking up employment with it, it is possible to conventionally divide the analysed reasons for openness to employment at a university into the following 5 groups:

1) key reasons - group 'A' — average values of 4.00 and above; 
2) very important reasons - group 'B' - average values from 3.50 to 3.99;

3) important reasons - group ' $\mathrm{C}$ ' - average values from 3.00 to 3.49 ;

4) medium important causes - group 'D' - average values from 2.00 to 2.99 ;

5) minor causes - group ' $\mathrm{E}$ ' - average values of 1.99 and below.

Table 2 shows that the identified causes of interest in taking up employment at a university belong only to 3 out of 5 contractually agreed groups. None of the reasons were in groups ' $\mathrm{C}$ ' and ' $\mathrm{E}$ '. It is also worth noting that the biggest differences in the values of average scores are among the key reasons (the difference between the extreme reasons in this group is 0.48 ). The smallest differences are visible in group ' $\mathrm{D}$ ' (the difference between extreme reasons is only 0.17 , while for group 'B' it is 0.27). This means that the respondents' opinions were relatively most divergent in relation to the individual reasons in group 'A', while the closest values were given to reasons in group ' $\mathrm{D}$ '.

The greatest value of the average score was 'possibility to share knowledge with others', and the lowest was 'more free time'. There was thus a difference of 1.71 between the reasons that took the extreme place in the hierarchy. It is worth noting, however, that each of the reasons received an average score of at least 2.77, which, using the five-stage Likert scale, proves that there are no such reasons among the analysed reasons, which were practically insignificant for the respondents.

It should also be noted that the reason related to job satisfaction was ranked 9 th, just before high salaries, whose average rating was almost equal to the same value. Higher positions were taken by reasons related to meeting social needs (e.g. 'high social prestige'), psychological needs (e.g. 'possibility to impress others'), or security needs (e.g. 'employment security and professional stability'). This means that if respondents representing young people are interested in working at a university, the hierarchy of needs is different from the classical Maslow approach, which may result from the age of the respondents and/or the specificity of the organisation, which is the university. Therefore, it would be worthwhile to subject this topic to further research. The statement contained in the $\mathrm{H} 1$ hypothesis in the case of respondents is therefore not true. 
Table 2. Classification of the reasons for the respondents' interest in the university as an employer in $\mathbf{2 0 1 9}$

\begin{tabular}{|c|c|c|c|}
\hline Analysed reason & Average value & Rank & Group \\
\hline $\begin{array}{l}\text { Possibility of sharing one's knowledge with others } \\
\text { Possibility of making a career } \\
\text { High social status } \\
\text { Positive overall impressions from studies }\end{array}$ & $\begin{array}{l}4.48 \\
4.13 \\
4.03 \\
4.00\end{array}$ & $\begin{array}{l}1 \\
2 \\
3 \\
4\end{array}$ & $\mathrm{~A}$ \\
\hline $\begin{array}{l}\text { Possibility to impress others } \\
\text { Employment security and stability } \\
\text { Willingness to introduce better standards } \\
\text { in university work and eliminate mistakes } \\
\text { made by lecturers } \\
\text { Positive experiences as a student related } \\
\text { to contacts with lecturers } \\
\text { Very responsible and difficult } \\
\text { but rewarding job } \\
\text { High salary }\end{array}$ & $\begin{array}{l}3.77 \\
3.76 \\
\\
3.68 \\
3.67\end{array}$ & $\begin{array}{r}7 \\
8 \\
8 \\
9\end{array}$ & $\mathrm{~B}$ \\
\hline $\begin{array}{l}\text { Possibility to "be forever young" through continuous } \\
\text { contact with young people } \\
\text { Very easy and pleasant job } \\
\text { More free time than in other places }\end{array}$ & $\begin{array}{l}2.94 \\
2.84 \\
2.77\end{array}$ & $\begin{array}{l}11 \\
12 \\
13\end{array}$ & $\mathrm{D}$ \\
\hline
\end{tabular}

Source: Own elaboration based on the results of conducted research.

The next stage of the analysis included a variable, i.e. opinions on the perception of people working at universities in Poland. The majority of respondents were of the opinion that such persons are better perceived in Poland than employees of other organisations, although this percentage only slightly exceeded half, amounting to $53.2 \%$. Slightly less than half of the respondents (46.1\%) believed that people working in universities are perceived in the same way as employees of other organisations, while only $0.7 \%$ of the respondents expressed the opinion that university employees are perceived worse than those employed by other employers. Due to the fact that the percentage of respondents expressing opinions about the worse perception was very small, for the purpose of the analysis, these answers were merged with 
answers about the same perception of university employees as employees of other organisations. In order to determine the internal structure of reasons for the interest in working at a university due to the perception of university staff, a factor analysis was carried out separately for two groups of respondents: 1/ persons who believe that university staff are perceived better; 2/ persons who believe that university staff are perceived in the same way or worse than those employed by other organisations.

On the basis of Kaiser's criterion, for each of the two groups of respondents 5 factors were distinguished, each with own values greater than 1 (Tables 3 and 5). The first factor for the respondents who, in the opinion of university employees, are perceived in the same way explains almost $25 \%$ of the total variability of the analysed phenomenon, i.e. much more than the first factor selected for those who indicate a better perception of university employees. The internal structure of these factors is also clearly different. For those who express an opinion on better perception of university staff, it includes 2 variables with factor loads of at least 0.7 (Table 4), while for those who indicate the same perception of university staff, the first factor is made up of 3 variables (Table 6). The specificity of variables in both contexts is also different. In the first case, these are the variables related to positive experiences from studies and sense of security. They can be classified as image aspects. For those who emphasise the same perception of university staff, on the other hand, the first factor variables have a completely different meaning, addressing what could be described as a common hedonistic issue. They concern a large amount of free time, ease of work and the preservation of 'eternal youth'.

The second factor for those who believe that scholarly staff are better perceived includes 2 variables that reflect the desire to preserve youth and to improve the way they fulfill their duties as university staff. Therefore, it can be described as hedonistic-reforming. On the other hand, an analogous factor distinguished for respondents indicating the same perception of university staff includes 3 variables with a more uniform resonance. They reflect aspirational aspects in both material and non-material dimensions. 
Table 3. Hierarchy of factors due to their own values determined on the basis of Kaiser's criterion (for respondents who believe that university employees are better perceived in Poland than employees of other organisations)

\begin{tabular}{c|c|c|c|c}
\hline Factor & $\begin{array}{c}\text { Own } \\
\text { value }\end{array}$ & $\begin{array}{c}\text { Accumulated } \\
\text { own value }\end{array}$ & $\begin{array}{c}\text { \% of total own value } \\
\text { (variant) }\end{array}$ & $\begin{array}{c}\text { Accumulated } \\
\text { \% of own value }\end{array}$ \\
\hline & 2.288 & 2.288 & 17.602 & 17.602 \\
2 & 2.211 & 4.499 & 17.009 & 34.611 \\
3 & 2.210 & 6.709 & 16.999 & 51.609 \\
4 & 1.894 & 8.603 & 14.567 & 66.177 \\
5 & 1.643 & 10.246 & 12.636 & 78.813 \\
\hline
\end{tabular}

Source: Own elaboration based on the results of conducted research.

The third factor in both contexts includes 2 variables each. It is worth noting that it was only in this factor that a variable reflecting job satisfaction appeared in the case of people expressing opinions on the same perception of university staff. This variable independently creates the fourth factor for those who indicate a better perception of persons employed in higher education institutions. In the case of both analysed groups of persons, the fourth and fifth factors are created by single variables. It should be noted that the only analogous factor in both cases is factor five, i.e. relatively insignificant, as it explains the smallest part of the total variability of the analysed phenomenon. It is formed by a variable referring to the possibility of impressing others. It is also worth noting that 'sharing knowledge with others' was not in any factor, either in one or the other group, although it took the first position in the hierarchy based on average scores.

The results of factor analysis allow for the typology of respondents. In the case of conducting this analysis in relation to market attitudes or behaviours, the separated factors may be interpreted as segments (in the case of recipients of a specific organisation's offer) or types (in the case of recipients of a whole group of organisations' offer) of respondents (cf. B. Horn, W. Huang). As can be seen from Table 7, representatives of 
Table 4. Results of factorial analysis of the reasons for the respondents' interest in the university as a workplace (for respondents who believe that university employees are better perceived in Poland than employees of other organisations)

\begin{tabular}{|c|c|c|c|c|c|}
\hline \multirow{2}{*}{ Variable } & \multicolumn{5}{|c|}{ Factor } \\
\hline & 1 & 2 & 3 & 4 & 5 \\
\hline $\begin{array}{l}\text { Positive experiences as a student related } \\
\text { to contacts with lecturers }\end{array}$ & 0.745 & 0.417 & -0.205 & -0.055 & -0.209 \\
\hline Employment security and stability & 0.712 & 0.138 & 0.424 & 0.196 & -0.132 \\
\hline Possibility of making a career & 0.666 & -0.304 & -0.016 & 0.320 & 0.352 \\
\hline High social prestige & 0.640 & -0.301 & 0.508 & -0.046 & 0.064 \\
\hline $\begin{array}{l}\text { Possibility to "be forever young" through continuous } \\
\text { contact with young people }\end{array}$ & 0.135 & 0.903 & 0.144 & -0.087 & 0.138 \\
\hline $\begin{array}{l}\text { Willingness to introduce better standards in university work } \\
\text { and eliminate mistakes made by lecturers }\end{array}$ & -0.130 & 0.830 & -0.153 & 0.313 & -0.181 \\
\hline More free time than in other places & 0.071 & 0.535 & 0.307 & -0.434 & -0.493 \\
\hline Very easy and pleasant job & 0.081 & 0.139 & 0.860 & 0.079 & -0.060 \\
\hline High salary & 0.130 & -0.108 & 0.736 & 0.179 & 0.442 \\
\hline $\begin{array}{l}\text { Very responsible and difficult but rewarding } \\
\text { job }\end{array}$ & -0.073 & -0.033 & 0.407 & 0.790 & -0.144 \\
\hline Possibility of sharing one's knowledge with others & 0.214 & 0.101 & -0.086 & 0.691 & 0.200 \\
\hline Positive overall impressions from studies & 0.501 & 0.053 & 0.353 & 0.559 & -0.122 \\
\hline Possibility to impress others & -0.076 & 0.010 & 0.114 & -0.031 & 0.940 \\
\hline
\end{tabular}

Source: Own elaboration based on the results of conducted research.

Table 5. Hierarchy of factors due to their own values determined on the basis of Kaiser's criterion (for respondents who believe that university employees in Poland are perceived in the same way as employees of other organisations)

\begin{tabular}{c|c|c|c|c}
\hline Factor & $\begin{array}{c}\text { Own } \\
\text { value }\end{array}$ & $\begin{array}{c}\text { Accumulated } \\
\text { own value }\end{array}$ & $\begin{array}{c}\text { \% of total own value } \\
\text { (variant) }\end{array}$ & $\begin{array}{c}\text { Accumulated } \\
\text { \% of own value }\end{array}$ \\
\hline 1 & 3.212 & 3.212 & 24.711 & 24.711 \\
2 & 3.032 & 6.244 & 23.320 & 48.032 \\
3 & 2.101 & 8.345 & 16.159 & 64.191 \\
4 & 1.711 & 10.056 & 13.161 & 77.352 \\
5 & 1.567 & 11.623 & 12.057 & 89.409 \\
\hline
\end{tabular}

Source: Own elaboration based on the results of conducted research. 
Table 6. Results of factorial analysis of the reasons for the respondents' interest in the university as a workplace (for respondents who believe that university employees in Poland are perceived in the same way as employees of other organisations)

\begin{tabular}{|c|c|c|c|c|c|}
\hline \multirow{2}{*}{ Variable } & \multicolumn{5}{|c|}{ Factor } \\
\hline & 1 & 2 & 3 & 4 & 5 \\
\hline More free time than in other places & 0.934 & 0.199 & 0.112 & -0.050 & -0.044 \\
\hline Very easy and pleasant job & 0.882 & 0.303 & -0.194 & -0.041 & -0.096 \\
\hline $\begin{array}{l}\text { Possibility to "be forever young" through continuous } \\
\text { contact with young people }\end{array}$ & 0.718 & 0.340 & -0.480 & 0.215 & 0.251 \\
\hline High social prestige & 0.198 & 0.864 & -0.015 & -0.032 & 0.099 \\
\hline High salary & 0.336 & 0.766 & -0.364 & -0.084 & 0.237 \\
\hline Possibility of making a career & 0.491 & 0.728 & -0.087 & 0.056 & -0.164 \\
\hline Employment security and stability & -0.035 & 0.675 & 0.079 & 0.641 & 0.163 \\
\hline Possibility of sharing one's knowledge with others & -0.489 & 0.536 & 0.356 & 0.292 & 0.071 \\
\hline Positive overall impressions from studies & -0.284 & -0.249 & 0.889 & 0.082 & -0.142 \\
\hline $\begin{array}{l}\text { Very responsible and difficult but } \\
\text { rewarding job }\end{array}$ & 0.101 & 0.134 & 0.779 & 0.434 & 0.123 \\
\hline $\begin{array}{l}\text { Positive experiences as a student related to } \\
\text { contacts with lecturers }\end{array}$ & -0.004 & -0.059 & 0.232 & 0.926 & 0.030 \\
\hline Possibility to impress others & 0.013 & 0.044 & -0.114 & 0.162 & 0.959 \\
\hline $\begin{array}{l}\text { Willingness to introduce better standards in university } \\
\text { work and eliminate mistakes made } \\
\text { by lecturers }\end{array}$ & 0.568 & -0.304 & -0.289 & 0.272 & -0.643 \\
\hline
\end{tabular}

Source: Own elaboration based on the results of conducted research.

particular types of respondents indicate homogeneous reasons for their interest in working at a university. On the other hand, there are clear differences between the individual types of respondents, separated according to their opinions on the perception of university staff compared to employees of other organisations, which confirms the conclusions drawn earlier. The statement contained in the research hypothesis $\mathrm{H} 2$ in the case of the respondents turned out to be true. It is worth noting that the reasons which took a place in the hierarchy in group 'A' turned out to be more important for those who believe that university employees in Poland are perceived in the same way as 
employees of other organisations. The second of the distinguished types of respondents (symbolically referred to as aspiring) within this group of people indicated precisely these reasons for their interest in working at a university.

Table 7. Identified types of respondents due to their opinions on the perception of people working at universities in Poland

\begin{tabular}{|c|c|c|}
\hline \multirow[t]{2}{*}{ Type } & \multicolumn{2}{|c|}{ Segment characteristics } \\
\hline & $\begin{array}{l}\text { for respondents who believe that university } \\
\text { employees are better perceived in Poland } \\
\text { than employees of other organisations }\end{array}$ & $\begin{array}{l}\text { for respondents who believe that university } \\
\text { employees in Poland are perceived in the same } \\
\text { way as employees of other organisations }\end{array}$ \\
\hline 1 & $\begin{array}{l}\text { Reputational } \\
\text { - positive experiences as a student related } \\
\text { to contacts with lecturers } \\
\text { - employment security and stability }\end{array}$ & $\begin{array}{l}\text { Hedonistic } \\
\text { - more free time than in other places } \\
\text { - bardzo łatwa i przyjemna praca } \\
\text { - possibility to "be forever young" through } \\
\text { continuous contact with young people }\end{array}$ \\
\hline 2 & $\begin{array}{l}\text { Hedonistic and transformative } \\
\text { - possibility to "be forever young" through } \\
\text { continuous contact with young people } \\
\text { - willingness to introduce better standards } \\
\text { in university work and eliminate mistakes } \\
\text { made by lecturers }\end{array}$ & $\begin{array}{l}\text { Aspirational } \\
\text { - high social prestige } \\
\text { - high salary } \\
\text { - possibility of making a career }\end{array}$ \\
\hline 3 & $\begin{array}{l}\text { Hedonistic } \\
\text { - very easy and pleasant job } \\
\text { - high salary }\end{array}$ & $\begin{array}{l}\text { Reputational and self-fulfilling } \\
\text { - positive overall impressions from studies } \\
\text { - very responsible and difficult } \\
\text { but rewarding job }\end{array}$ \\
\hline 4 & $\begin{array}{l}\text { Self-fulfilling } \\
\text { - very responsible and difficult but } \\
\text { rewarding job }\end{array}$ & $\begin{array}{l}\text { Reputational } \\
\text { - positive experiences as a student } \\
\text { related to contacts with lecturers }\end{array}$ \\
\hline 5 & $\frac{\text { Snobbish }}{\text { - possibility to impress others }}$ & $\frac{\text { Snobbish }}{\text { - possibility to impress others }}$ \\
\hline
\end{tabular}

Source: Own elaboration based on the results of conducted research. 
Table 8. Analysis of the significance of differences between the respondents' answers concerning the reasons for the interest in a university as a workplace due to the criterion of their opinions concerning the perception in Poland of people working in a university

\begin{tabular}{|c|c|c|c|}
\hline Variable & $\begin{array}{l}\text { Opinions on perception of persons } \\
\text { working in a higher education institution }\end{array}$ & $\begin{array}{c}\text { KW test } \\
\text { value }\end{array}$ & $\begin{array}{l}\text { Signifi- } \\
\text { cance } \\
\text { level 'p' }\end{array}$ \\
\hline Very easy and pleasant job & $\begin{array}{l}\text { better than persons working in other institutions } \\
\text { the same as persons working for other institutions }\end{array}$ & $\begin{array}{l}15.33 \\
17.23\end{array}$ & 0.560 \\
\hline High social prestige & $\begin{array}{l}\text { better than persons working in other institutions } \\
\text { the same as persons working for other institutions }\end{array}$ & $\begin{array}{l}18.40 \\
11.64\end{array}$ & 0.025 \\
\hline High salary & $\begin{array}{l}\text { better than persons working in other institutions } \\
\text { the same as persons working for other institutions }\end{array}$ & $\begin{array}{l}18.53 \\
11.41\end{array}$ & 0.026 \\
\hline Possibility of making a career & $\begin{array}{l}\text { better than persons working in other institutions } \\
\text { the same as persons working for other institutions }\end{array}$ & $\begin{array}{l}17.58 \\
13.14\end{array}$ & 0.133 \\
\hline Employment security and stability & $\begin{array}{l}\text { better than persons working in other institutions } \\
\text { the same as persons working for other institutions }\end{array}$ & $\begin{array}{l}16.75 \\
14.64\end{array}$ & 0.492 \\
\hline $\begin{array}{l}\text { Possibility of sharing one's knowledge } \\
\text { with others }\end{array}$ & $\begin{array}{l}\text { better than persons working in other institutions } \\
\text { the same as persons working for other institutions }\end{array}$ & $\begin{array}{l}17.50 \\
13.27\end{array}$ & 0.158 \\
\hline Possibility to impress others & $\begin{array}{l}\text { better than persons working in other institutions } \\
\text { the same as persons working for other institutions }\end{array}$ & $\begin{array}{l}17.30 \\
13.64\end{array}$ & 0.218 \\
\hline $\begin{array}{l}\text { Possibility to "be forever young" through } \\
\text { continuous contact with young people }\end{array}$ & $\begin{array}{l}\text { better than persons working in other institutions } \\
\text { the same as persons working for other institutions }\end{array}$ & $\begin{array}{l}16.60 \\
14.91\end{array}$ & 0.605 \\
\hline More free time than in other places & $\begin{array}{l}\text { better than persons working in other institutions } \\
\text { the same as persons working for other institutions }\end{array}$ & $\begin{array}{l}14.88 \\
18.05\end{array}$ & 0.329 \\
\hline $\begin{array}{l}\text { Very responsible and difficult } \\
\text { but rewarding job }\end{array}$ & $\begin{array}{l}\text { better than persons working in other institutions } \\
\text { the same as persons working for other institutions }\end{array}$ & $\begin{array}{l}16.03 \\
15.95\end{array}$ & 0.983 \\
\hline Positive overall experiences from studies & $\begin{array}{l}\text { better than persons working in other institutions } \\
\text { the same as persons working for other institutions }\end{array}$ & $\begin{array}{l}16.33 \\
15.41\end{array}$ & 0.774 \\
\hline $\begin{array}{l}\text { Positive experiences as a student } \\
\text { related to contacts with lecturers }\end{array}$ & $\begin{array}{l}\text { better than persons working in other institutions } \\
\text { the same as persons working for other institutions }\end{array}$ & $\begin{array}{l}17.70 \\
12.91\end{array}$ & 0.143 \\
\hline $\begin{array}{l}\text { Willingness to introduce better } \\
\text { standards in university work and } \\
\text { eliminate mistakes made by lecturers }\end{array}$ & $\begin{array}{l}\text { better than persons working in other institutions } \\
\text { the same as persons working for other institutions }\end{array}$ & $\begin{array}{l}14.98 \\
17.86\end{array}$ & 0.377 \\
\hline
\end{tabular}

Source: Own elaboration based on research results. 
At the last stage of the analysis, an attempt was made to check whether the opinions on the perception of people working at universities in Poland in comparison with the perception of employees of other organisations are a differentiating feature of the reasons indicated by the respondents for their interest in working at universities. For this purpose, the Kruskal-Wallis test was used. Its results indicate that there is a statistically significant variation in the case of two reasons, which they are: The results of the study show that there is a statistically significant variation for two reasons: 'high social prestige' and 'high salary'. Only for these variables the significance level ' $p$ ' was smaller than 0.05 , while slightly greater differentiation was identified in the case of the latter variable. The statement contained in the H3 hypothesis of the case of respondents turned out to be true only for these 2 reasons.

\section{Summary}

On the basis of the presented considerations, it can be stated that almost every fourth respondent declared interest in taking up employment at a university. The main reasons for this interest were: the possibility of sharing one's knowledge with others; possibility of making a career ; high social prestige; positive overall impressions from studies. They did not include the expected job satisfaction. Therefore, it can be said that the statement contained in the research hypothesis $\mathrm{H} 1$ in the case of respondents is not true. The research also took into account a variable, which is the perception of university employees in Poland in comparison with persons employed in other organisations. Over 53\% of all respondents believed that university employees are perceived better. The results of factor analysis conducted for people expressing such an opinion and for people with different opinions indicate that there is a different internal structure of reasons for interest in working at a university. Thus, the statement contained in the research hypothesis $\mathrm{H} 2$ in the case of respondents turned out to be true. Opinions on the perception of university staff were a differentiating feature of the 
indications concerning the reasons for the interest in employment in a university for only two reasons: high prestige and high salaries. Therefore, only for them can we say that the statement contained in the research hypothesis $\mathrm{H} 3$ in the case of respondents is true.

The results obtained have a high cognitive and application value. They make it easier for university authorities to take appropriate personal actions aimed at the representatives identified during the survey as the types of recipients of the personnel offer. In this context, it is particularly important to adapt these activities to their expectations. The specific requirements of the identified types of representatives indicate, for example, that possible interest in working at a university is influenced by relational aspects characterising contacts between students and lecturers. Therefore, already at this stage of mutual relations, it is worth seeing in students co-creators of the image of the university, some of which may in the future become potential employees directly interested in the personnel offer of a given university as an employer.

Of course, the research carried out has certain limitations. They include their scope: subjective (only representatives of young potential employees), geographical (only representatives of Polish young potential employees), objective (lack of in-depth analysis of particular causes). In order to eliminate these limitations, in subsequent stages of the research process concerning the reasons for the interest in universities as employers, it is planned to broaden each of the above mentioned areas by also covering universities as employers and representatives of young potential employees from other countries. This will make it possible to conduct comparative analysis in terms of entities and geography. So far, three editions of the research have been carried out, gradually extending their scope. It is planned to continue them in the future so that comparative analysis can be carried out in a time perspective.

\section{References}

1 The first edition of the study was preceded by unstructured interviews conducted among 50 people.

2 Each time a random sample selection was used, taking into account the opinion of M. Szreder (2010) that not always a random selection is better. 


\section{Bibliography}

1. Abdi, H., Williams, L. J. (2010). Principal component analysis. Wiley Interdisciplinary Reviews: Computational Statistics, Vol. 2, Iss. 4, pp. 433-459.

2. Abduli, S. (2013). Effective Human Resource Management in Small and Medium Size Enterprises in the Republic of Macedonia. International Journal of Academic Research in Economics and Management Sciences, Vol. 2, No. 2, pp. 169-183.

3. Acikgoz, Y. (2019). Employee recruitment and job search: Towards a multi-level integration. Human Resource Management Review, Vol. 29, Iss, 1, pp. 1-13.

4. Baruk, A., Goliszek, A. (2018). Zmiany skojarzeń z uczelnią jako pracodawcą — opinie młodych polskich potencjalnych pracowników. Marketing Instytucji Naukowych i Badawczych, Vol. 28, Iss. 2, pp. 1-18.

5. Bhalla, G. (2016). Collaboration and Co-Creation: The Road to Creating Value. The Marketing Journal, Vol. May, http://www.marketingjournal.org/collaboration-and-co-creation-the-road-to-creating-value/ (accessed on 10.07.2019).

6. Bombiak, E., Marciniuk-Kluska, A. (2019). Socially Responsible Human Resource Management as a Concept of Fostering Sustainable Organization-Building: Experiences of Young Polish Companies. Sustainability, Vol. 11, Iss. 4, p. 1044.

7. Chakravarthy, S., Prasad, G.V.B. (2011). The Impact of Opinion Leader on Consumer Decision Making Process. International Journal of Management \& Business Studies, Vol. 1, Iss. 3, pp. 61-64.

8. Chhinzer N., Russo A.M. (2018). An exploration of employer perceptions of graduate student employability. Education + Training, Vol. 60, Iss. 1, pp. 104-120.

9. Felix, E. (2015). Marketing Challenges of Satisfying Consumers Changing Expectations and Preferences in a Competitive Market. International Journal of Marketing Studies, Vol. 7, No. 5, pp. 41-52.

10. Hadiyati, E. (2016). Study of marketing mix and AIDA model to purchasing on line product in Indonesia. British Journal of Marketing Studies, Vol. 4, No. 7, pp. 49-62.

11. Hassan, S., Nadzim, S.Z.A., Shiratuddin, N. (2015). Strategic Use of Social Media for Small Business Based on the AIDA Model. Procedia - Social and Behavioral Sciences, Vol. 172, pp. 262-269.

12. Horn, B., Huang, W. Comparison of Segmentation Approaches, https://www.decisionanalyst.com/whitepapers/comparesegmentation/ (accessed on 04.04.2019).

13. http://www.statystycy.pl/t4997_1_test_rangowy_kruskala-wallisa.php (dostęp: 18.05.2019).

14. http://www.statystyka.az.l/test-anova-kruskala-wallisa.php (accessed on 18.05.2019).

15. Huang, T.-C. (2000). Are the human resource practices of effective firms distinctly different from those of poorly performing ones? Evidence from Taiwanese enterprises. The International Journal of Human Resource Management, Vol. 11, Iss. 2, pp. 436-451.

16. Huete-Alcocer, N. (2017). A Literature Review of Word of Mouth and Electronic Word of Mouth: Implications for Consumer Behavior. Frontiers in Psychology, Vol. 8, pp. 1-4.

17. Livette, M. (2007). Influencer and other „buying” roles in the decision-making process of retirement housing purchasers. Property Management, Vol. 25, Iss. 3, pp. 242-256.

18. Madanat, H.G., Khasawneh, A. S. (2018). Level of effectiveness of human resource management practices and its impact on employees" satisfaction in the banking sector of Jordan. Journal of Organizational Culture. Communications and Conflict, Vol. 22, Iss. 1, pp. 1-19. 
19. Mattingly, V., Kraiger, K. (2019). Can emotional intelligence be trained? A meta-analytical investigation. Human Resource Management Review, Vol. 29, Iss. 2, pp. 140-155.

20. Mazur, B. (2014). Sustainable Human Resource Management in theory and practice. Economics and Management, Vol. 1, pp. 158-170.

21. Michel, J.W., Tews, M.J., Allen, D. G. (2019). Fun in the workplace: A review and expanded theoretical perspective. Human Resource Management Review, Vol. 29, Iss. 1, pp. 98-110.

22. Müceldili, B., Erdil, O. (2016). Finding Fun in Work: The Effect of Workplace Fun on Taking Charge and Job Engagement. Procedia - Social and Behavioral Sciences, Vol. 235, Iss. 24, pp. 304-312.

23. Olejniczak, A. (2019), Uwarunkowania stosowania koncepcji otwartych innowacji $w$ instytucjach naukowych $i$ badawczo-rozwojowych, Niepublikowana rozprawa doktorska przygotowana pod kierunkiem naukowym A. Baruk, http://wzip.p.lodz.pl/wp-content/uploads/2019/06/streszczenie_pol_olejniczak.pdf (accessed on 10.07.2019).

24. Özdemira, A., Tozlub, E., Æenc, E., Ateæoglu, H. (2016). Analyses of Word-of-mouth Communication and its Effect on Students' University Preferences. Procedia - Social and Behavioral Sciences, Vol. 235, Iss. 24, pp. 22-35.

25. Ramaswamy, V., Ozcan, K. (2014). The Co-Creation Paradigm. Stanford University Press, Stanford.

26. Robers, D.L., Darler, W. (2017). Consumer Co-Creation: An Opportunity to Humanise the New Product Development Process. International Journal of Market Research, Vol. 59, Iss. 1, pp. 13-33.

27. Schnurr, B., Brunner-Sperdin, A., Stokburger-Sauer, N.E. (2017). The effect of context attractiveness on product attractiveness and product quality: the moderating role of product familiarity. Marketing Letters, Vol. 28, Iss, 2, pp. 241-253.

28. Stankevich, A. (2017). Explaining the Consumer Decision-Making Process: Critical Literature Review. Journal of International Business Research and Marketing, Vol. 2, Iss. 6, pp. 7-14.

29. Stone, D.L., Deadrick, D.L., Lukaszewski, K.M., Johnson, R. (2015). The influence of technology on the future of human resource management. Human Resource Management Review, Vol. 25, Iss. 2, pp. 216-231.

30. Szreder, M. (2010). Losowe i nielosowe próby w badaniach statystycznych. Przegląd Statystyczny, Vol. 4, pp. 168-174.

31. Sztemberg-Lewandowska, M. (2008). Analiza czynnikowa w badaniach marketingowych. Wydawnictwo Uniwersytetu Ekonomicznego we Wrocławiu, Wrocław, p. 29.

32. Tóth-Téglás, T., Hlédik, E., Fónadová, L. (2016). An Analysis of Employer Requirements of University Graduates. Acta Polytechnica Hungarica, Vol. 13, No. 5, pp. 169-188.

33. Visa, A., Einolander, J., Vanharanta, H. (2015). New Tools to Help in the Recruitment Process. Procedia Manufacturing, Vol. 3, pp. 653-659.

34. Voegtlin, Ch., Greenwood, M. (2016). Corporate social responsibility and human resource management: A systematic review and conceptual analysis. Human Resource Management Review, Vol. 3, pp. 181-197.

35. Willman-Iivarinen, H. (2017). The future of consumer decision making. European Journal of Futures Research, Vol. 5, pp. 14-20. 
36. Writer, F. (2014). The Co-Creation Paradigm. Strategic Direction, Vol. 30, Iss. 10, pp. 7-14.

Professor Agnieszka Izabela Baruk, Łódź University of Technology, Poland - lecturer at Lodz University of Technology, Faculty of Management and Production Engineering, Department of Management Systems and Innovation. Her publications comprise 434 peer-reviewed positions including 14 books about transaction and personal marketing and their mutual interdependencies. 